\title{
Teaching NeuroImages: Neurovascular features of suspected antenatal-onset Sturge-Weber syndrome without skin involvement
}

Silvia Martini, MD, Francesco Toni, MD, Vittoria Paoletti, PhD, Luigi Corvaglia, MD, and Duccio Maria Cordelli, MD

Neurology ${ }^{\circledR}$ 2020;95:e3070-e3071. doi:10.1212/WNL.0000000000010759

Figure 1 Bilateral electroencephalography/amplitude-integrated electroencephalography and near-infrared spectroscopy patterns

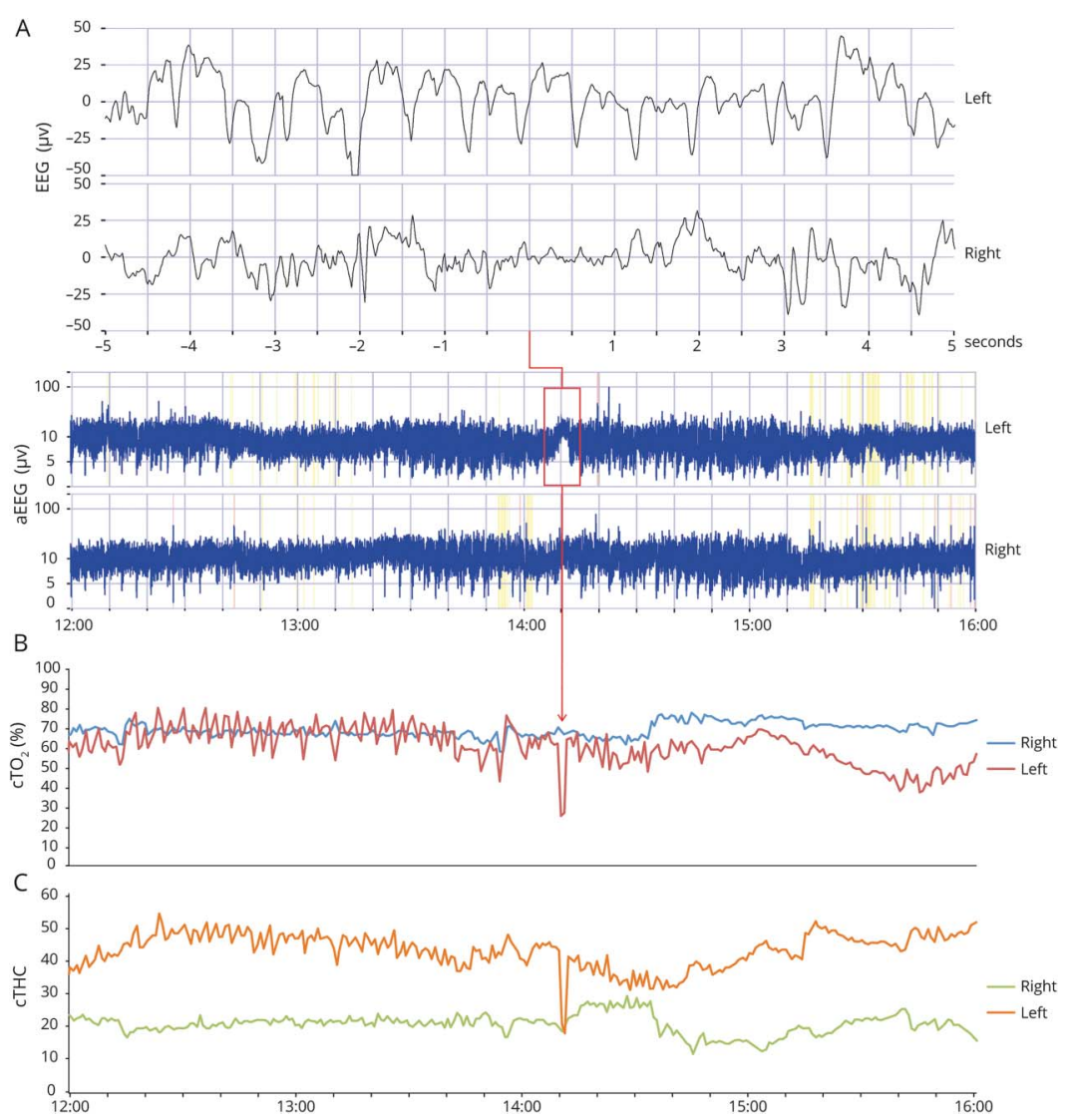

Electroencephalography/amplitude-integrated electroencephalography (A), cerebral oxygenation ( $\mathrm{CTO}_{2}$, B), and total hemoglobin concentration (CTHC, C) patterns. The electrical seizure in the left hemisphere is accompanied by simultaneous ipsilateral acute changes in $\mathrm{CTO}_{2}$ and $\mathrm{CTHC}$ in the left frontoparietal lobe (red arrow), detected using a NIRO-200NX oximeter (Hamamatsu, Japan).

A female infant was born at 35-week gestation by emergency C-section because of abnormal cardiotocography. No birthmarks were evident. Cord $\mathrm{pH}$ was 6.87; therefore, an amplitudeintegrated electroencephalography monitoring was performed soon after birth, showing leftsided electrical seizures. Cranial ultrasound revealed left hemisphere atrophy, with subcortical
Correspondence

Dr. Martini

silvia.martini9@unibo.it

\section{MORE ONLINE}

$\rightarrow$ Teaching slides

links.lww.com/WNL/

B206

From the Neonatal Intensive Care Unit (S.M., V.P., L.C.), S. Orsola-Malpighi University Hospital; Department of Medical and Surgical Sciences (DIMEC) (S.M., L.C., D.M.C.), University of Bologna; IRCCS Istituto delle Scienze Neurologiche di Bologna (F.T.), UOC Neuroradiologia; and Child Neurology and Psychiatry Unit (D.M.C.), S. Orsola-Malpighi University Hospital, Bologna, Italy.

Go to Neurology.org/N for full disclosures. Funding information and disclosures deemed relevant by the authors, if any, are provided at the end of the article. 
Figure 2 Neuroradiologic findings

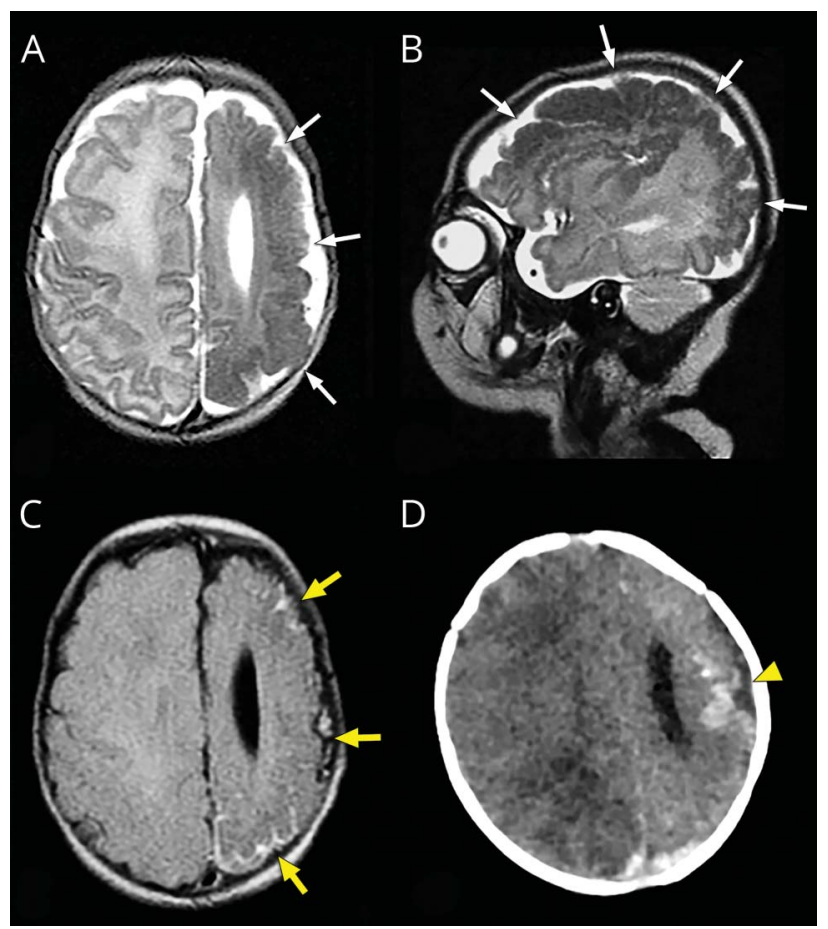

Left hemispheric atrophy with perisylvian polymicrogyria on T2-weighted axial (A) and sagittal (B) views (white arrows), ipsilateral frontoparietal leptomeningeal angiomatosis (postgadolinium axial FLAIR T2-weighted scan yellow arrows) (C), and focal calcifications (axial CT scan, yellow arrowhead) (D). Left hemispheric T2 hypointensity (A and B) may be related to venous congestion or accelerated myelination.

hyperechoic areas in the frontoparietal lobe. Frontoparietal NIRS monitoring showed interhemispheric asymmetry of cerebral oxygenation and total hemoglobin concentration (figure 1) that serves as a proxy for cerebral blood volume. ${ }^{1}$ Brain CT and MRI (figure 2) revealed characteristic features consistent with Sturge-Weber syndrome. Based on the evidence of polymicrogyria, the insult was dated back to the second trimester of pregnancy. ${ }^{2}$ The ophthalmologic examination results were unremarkable. The infant was started on phenobarbital, ${ }^{3}$ with seizure remission.

\section{Study funding}

No targeted funding reported.

\section{Disclosure}

The authors report no disclosures relevant to the manuscript. Go to Neurology.org/N for full disclosures.

Appendix Authors

\begin{tabular}{lll}
\hline Name & Location & Contribution \\
\hline $\begin{array}{l}\text { Silvia } \\
\text { Martini, }\end{array}$ & $\begin{array}{l}\text { S. Orsola-Malpighi } \\
\text { University Hospital, } \\
\text { Bologna, Italy }\end{array}$ & $\begin{array}{l}\text { Acquired and analyzed NIRS } \\
\text { and aEEG data and drafted the } \\
\text { manuscript for intellectual } \\
\text { content. }\end{array}$ \\
$\begin{array}{l}\text { Francesco } \\
\text { Toni, MD }\end{array}$ & $\begin{array}{l}\text { IRCCS Istituto delle } \\
\text { Scienze Neurologiche, } \\
\text { Bologna, Italy }\end{array}$ & $\begin{array}{l}\text { Acquired and analyzed } \\
\text { neuroimaging data and } \\
\text { revised the manuscript for } \\
\text { intellectual content. }\end{array}$ \\
$\begin{array}{l}\text { Vittoria } \\
\text { Paoletti, } \\
\text { PhD }\end{array}$ & $\begin{array}{l}\text { S. Orsola-Malpighi } \\
\text { Bologna, Italy }\end{array}$ & $\begin{array}{l}\text { Contributed to NIRS data } \\
\text { acquisition and revised the } \\
\text { manuscript for intellectual } \\
\text { content. }\end{array}$ \\
$\begin{array}{l}\text { Luigi } \\
\text { Corvaglia, } \\
\text { MD }\end{array}$ & $\begin{array}{l}\text { S. Orsola-Malpighi } \\
\text { Bologna, Italy }\end{array}$ & $\begin{array}{l}\text { Interpreted the data and } \\
\text { revised the manuscript for } \\
\text { intellectual content. }\end{array}$ \\
\hline $\begin{array}{l}\text { Duccio } \\
\text { Maria } \\
\text { Cordelli, } \\
\text { MD }\end{array}$ & $\begin{array}{l}\text { S. Orsola-Malpighi } \\
\text { Bniversity Hospital, }\end{array}$ & $\begin{array}{l}\text { Interpreted the data and } \\
\text { revised the manuscript for } \\
\text { intellectual content }\end{array}$ \\
\hline
\end{tabular}

\section{References}

1. Wyatt JS, Edwards AD, Cope M, et al. Response of cerebral blood volume to changes in arterial carbon dioxide tension in preterm and term infants. Pediatr Res 1991;29:553-557.

2. Bachur CD, Comi AM. Sturge-weber syndrome. Curr Treat Options Neurol 2013;15: 607-617.

3. Day AM, Hammill AM, Juhász C, et al. Hypothesis: presymptomatic treatment of Sturge-Weber syndrome with aspirin and antiepileptic drugs may delay seizure onset. Pediatr Neurol 2019;90:8-12. 


\section{Neurology}

\section{Teaching NeuroImages: Neurovascular features of suspected antenatal-onset Sturge-Weber syndrome without skin involvement Silvia Martini, Francesco Toni, Vittoria Paoletti, et al.}

Neurology 2020;95;e3070-e3071 Published Online before print September 4, 2020

DOI 10.1212/WNL.0000000000010759

This information is current as of September 4, 2020

Updated Information \& Services

References

Subspecialty Collections

Permissions \& Licensing

Reprints including high resolution figures, can be found at: http://n.neurology.org/content/95/22/e3070.full

This article cites 3 articles, 0 of which you can access for free at: http://n.neurology.org/content/95/22/e3070.full\#ref-list-1

This article, along with others on similar topics, appears in the following collection(s):

CT

http://n.neurology.org/cgi/collection/ct

MRI

http://n.neurology.org/cgi/collection/mri

Near Infrared Spectroscopy (NIRS)

http://n.neurology.org/cgi/collection/near_infrared_spectroscopy_nirs Neonatal

http://n.neurology.org/cgi/collection/neonatal

Information about reproducing this article in parts (figures,tables) or in its entirety can be found online at:

http://www.neurology.org/about/about_the_journal\#permissions

Information about ordering reprints can be found online:

http://n.neurology.org/subscribers/advertise

Neurology ${ }^{\circledR}$ is the official journal of the American Academy of Neurology. Published continuously since 1951, it is now a weekly with 48 issues per year. Copyright @ 2020 American Academy of Neurology. All rights reserved. Print ISSN: 0028-3878. Online ISSN: 1526-632X.

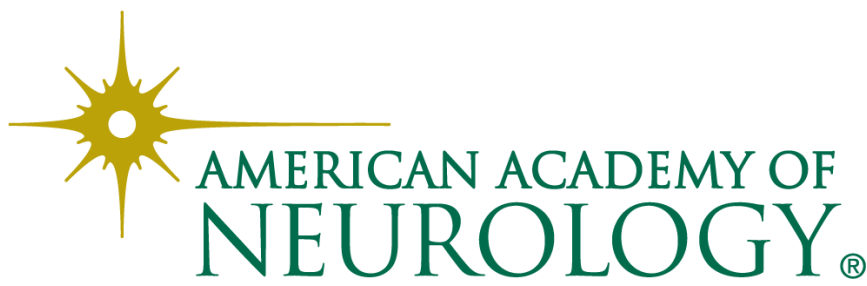

